\title{
PENENTUAN KUALITAS BIJI KOPI ARABIKA DENGAN MENGGUNAKAN ANALYTICAL HIERARCHY PROCESS (STUDI KASUS PADA PERKEBUNAN KOPI LERENG GUNUNG KELIR JAMBU SEMARANG)
}

\author{
Wahyu Muhammad Kurniawan \\ Fakultas Ilmu Komputer, Program Studi Teknik Informatika \\ Universitas Dian Nuswantoro \\ Email: wahyumk9f@gmail.com \\ Khafiizh Hastuti \\ Fakultas Ilmu Komputer, Program Studi Teknik Informatika \\ Universitas Dian Nuswantoro \\ Email: afis@dsn.dinus.ac.id
}

\begin{abstract}
ABSTRAK
Penentuan kualitas biji kopi pada dasarnya memerlukan keahlian dan pengecekan terhadap biji kopi yang membutuhkan waktu tidak sedikit dalam menentukannya. Kriteria penentuan kualitas biji kopi sebelumnya sudah diatur dalam skala internasional. Dalam menentukan kualitas biji kopi didalam skala nasional tiap-tiap instansi mempunyai kriteria tersendiri dalam menentukan kualitas biji kopi yang tentunya juga mengacu pada kriteria penentuan kualitas biji kopi skala internasional. Sebagai salah satu perkebunan yang ada di Indonesia, perkebunan kopi Gunung Kelir Jambu Semarang tentu menggunakan penentuan kualitas dalam memproduksi biji kopi. Dimana kriteria yang digunakan adalah nilai kadar air, nilai cacat biji, dan ketinggian lahan dimana kopi tersebut ditanam. Dengan penentuan kualitas biji kopi arabika dengan kriteria kadar air, cacat biji dan ketinggian lahan pada Perkebunan Kopi Lereng Gunung Kelir Jambu Seamrang, pada peneitian ini menggunakan metode AHP. Dimana metode AHP dapat menghasilkan output berupa perangkingan yang dihitung berdasarkan input dan nilai bobot yang mana nilai bobot tersebut dapat disesuaikan dengan penentuan kriteria yang akan diterapkan. Hasil dari penelitian berupa suatu aplikasi yang dapat menentukan kualitas biji kopi dengan input kadar air, cacat biji, dan ketinggian lahan dengan menggunakan metode AHP (Analytical Heirarchy Process).
\end{abstract}

Kata kunci: kopi arabika, kualitas, analytical hierarchy process.

\begin{abstract}
Determination the quality of arabika coffee beans basically requires expertise and checks on coffe beans that require time not a bit in determining it. The criteria for determining the qualiy of the previous beans have been arranged on an international scale. In determining the quality of cpffe beans on national scale each agency has its own criteria in determining the quality of coffe beans. As on of the existing plantations in Indonesia, coffee plantations of Mount Kelir Jambu Semarang certainly use the determination of quality in producing coffee beans. Where the criteria used are the value of moisture content, the defect value of the seed, and the height of the land where the coffee is grown. By determining the quality of arabica coffee beans with water content criteria, defects of seeds and altitude of land on Coffee Plantations Slopes Mount Kelir Jambu Seamrang, in this study using AHP method. Where the AHP method can produce output in the form of rankings that are calculated based on the input and weight value which the weight value can be adjusted with the determination of the criteria to be applied. The result of the research is an application that can determine the quality of coffee beans with water content, seed defects, and altitude using AHP (Analytical Heirarchy Process) method.
\end{abstract}

Keywords: arabica coffee, quality, analytical hierarchy process.

\section{PENDAHULUAN}

Indonesia merupakan negara penghasil kopi terbersar keempat di dunia setelah Brazil, Vietnam, dan Colombia. Dari total produksi yang dihasilkan sekitar $67 \%$ kopi diekspor dan sisanya 33\% untuk memenuhi kebutuhan dalam negeri. Tingkat konsumsi kopi di Indonesia sebesar 500 gram/kapita/tahun berdasarkan hasil survey LPEM UI(Lembaga Penelitian Ekonomi Manajemen Universitas Indonesia, 
1989). Dengan begitu dalam kurun waktu 20 tahun konsumsi kopi akan mengalami peningkatan hingga mencapai 300 gram/kapita/tahun [1].

Industri kopi di Indonesia sangat beragam, dimulai dari unit usaha kecil yang berskala industri rumahan sampai industri kopi berskala multinasional. Produk yang dihasilkan tidak hanya diproduksi untuk kebutuhan dalam negeri melainkan juga untuk mengisi pasar di luar negeri. Hal ini menunjukkan bahwa konsumsi kopi dalam negeri merupakan peluang pasar yang sangat menarik bagi kalangan pengusaha dan memberikan peluang adanya kondusi yang kondusif dalam berinvestasi dibidang industri kopi. Perkembangan konsumsi kopi ini namun tidak di imbangi dengan kelancaran dalam produksi biji kopi itu sendiri serta pemilihan kualitas yang baik untuk pengolahannya [2].

Di Indonesia sendiri menerapkan standar nasional kualitas atau mutu suatu biji kopi yakni dengan melihat faktor dari nilai cacat pada biji kopi. Persyaratan standar mutu biji kopi yang berlaku saat ini adalah Standar Nasional Indonesia nomor 01-2907-2008 dimana dengan menggunakan nilai cacat sebagai acuan untuk menentukan kualitas atau mutu suatu biji kopi. Penentuan kualitas biji kopi dengan menggunakan nilai cacat sebagai acuan masih dilakukan menggunakan perhitungan manual, dengan mengambil sample dan dihitung satu-persatu berapa banyak kecacatan yang ada pada tiap sampel biji kopi sesuai dengan ketentuan Standar Nasional Indonesia nomor 01-2907-2008 [2].

Dewan ICO (International Coffe Organization) awal tahun 2002 mengadakan siding dan menghasilkan Resolusi No. 407 yang berisi Program Perbaikan Mutu Kopi yang mulai diberlakukan per 1 Oktober 2002. Standar minimum Resolusi No. 407 tersebut adalah:

a. Kopi Arabika: nilai cacat maksimal 86 per 300gr sampel menurut standar mutu Brazil/New York

b. Kopi Robusta: Nilai cacat maksimal 150 per $300 \mathrm{gr}$ sampel menurut standar mutu Indonesia/Vietnam

c. Kadar Air: maks 12,5\% berdasarkan ISO 6673 [2]

Sebagai salah satu perkebunan yang ada di Indonesia, perkebunan kopi Gunung Kelir Jambu Semarang tentu menggunakan penentuan kualitas dalam memproduksi biji kopi. Terdapat persyaratan kualitas biji kopi yang sudah ditetapkan oleh perkebunan kopi Gunung Kelir Jambu Semarang dengan menggunakan nilai cacat, kadar air, dan ketinggian lahan yang ada pada biji kopi tiap karungnya. Saat ini perkebunan kopi Gunung Kelir Jambu Semarang masih menggunakan perhitungan manual dalam penentuan kualitasbiji kopi yang diproduksi.Hasil dari penentuan kualitasbiji kopi, lalu dicatat dalam sebuah laporan dengan menggunakan buku sebagai alat bantu dalam mengingat perhitungan kualitas dari biji kopi tersebut. Banyaknya perhitungan tersebut memungkinkan adanya kesalahan dalam pelabelankualitas tiap karung biji kopi yang sebelumnya sudah ditentukan kualitas dan nilai cacat nya.

Beberapa penelitian sebelumnya yang berkaitan dengan penentuan kualitas telah dilakukan oleh Eko Darmanto et al (2014) dengan judul "Penerapan Metode AHP (Analythic Hierarchy Process) Untuk Menentukan Kualitas Gula Tumbu" pada penelitian tersebut diteliti kualitas gula tumbu dengan menggunakan 3 parameter yag terdiri dari warna gula tumbu, rasa gula tumbu, dan kekerasan gula tumbu. Berdasarkan penelitian ini metode AHP dapat digunakan untuk mengetahui kualitas dari gula tumbu dengan menentukan bobot kriteria dari ketiga parameter lalu dibentuk sebuah matrik perbandingan berpasangan kemudian menghitung nilai eigen vector dan menguji konsistensinya berdasarkan tiap nilai eigen vector dari ketiga parameter tersebut. Pada penelitian tersebut menjelaskan bahwa hasil penelitian sudah mendekati sempurna. Data perhitungan dalam penelitian tersebut dapat diolah secara keseluruhan berdasarkan kriteria yang ada pada kriteria penentuan kualitas gula tumbu [3].

Penelitian selanjutnya dilakukan oleh Usep Tatang dan Rangga Eka (2015) dengan judul "Implementasi Algoritma C4.5 Dalam Penentuan Kualitas Tomat" pada penelitian tersebut diteliti kualitas tomat dengan menggunakan algoritma C4.5.Di dalam penelitian tersebut terdapat 3 parameter antara lain tampilan kondisi tomat, ukuran tomat, dan nama penyakit pada tomat. Pada parameter tampilan kondisi tomat dan ukuran tomat diklasifikasi menjadi 3 jenis berdasarkan syarat atau aturan yang sudah ditentukan. Dari parameter yang sudah diklasifikasi tersebut kemudian dicari besar nilai entropy dan gain yang kemudian dari nilai entropy dan gain tersebut didapatkan kualitas tomat tersebut [4].

Penelitian selanjutnya dilakukan oleh Galuh Mazenda et al (2014) dengan judul "Implementasi Fuzzy Inference System (FIS) Metode Tsukamoto Pada Sistem Pendukung Keputusan Penentuan Kualitas Air Sungai". Pada dasarnya menghitung kualitas air dapat menggunakan cara manual dengan menggunakan perhitungan metode STORET. Dalam penelitian tersebut terdapat 7 parameter antara lain TAA, BOD, CD, DO, pH, Fenol, Minyak dan lemak.. Ketujuh parameter tersebut kemudian dilakukan fuzzyfikasi atau menghitung derajat keanggotaan untuk tiap kriteria yang akan menghasilkan pembentukan variabel dan himpunan fuzzy. Pada penelitian tersebut dapat diketahui bahwa metode Tsukamoto dapat digunakan dalam menentukan kualitas dari air sungai, akan tetapi pada penelitian tersebut menjelaskan bahwa kesesuaian metode Tsukamoto dalam menentukan kualitas air masih 90\% akurat apabila menghitung manual dengan metode STORET [5]. 
Berdasarkan latar belakang permasalahan dan paparan metode penyelesaian pada penelitian sebelumnya, peneliti mengusulkan dalam penentuan kualitas biji kopi menggunakan metode AHP (Analythic Hierarchy Process). Pada penelitian ini untuk menentukan kualitas biji kopi menggunakan nilai cacat sebagai acuan. Metode AHP (Analythic Hierarchy Process) dipilih sebagai metode untuk menentukan kualitas biji kopi karena metode AHP dapat menguraikan masalah yang multi faktor atau multi kriteria [3].

\section{METODOLOGI PENELITIAN}

Di dalam penelitian ini metode AHP adalah metode yang diusulkan untuk menentukan kualitas biji kopi arabika pada Perkebunan Lereng Gunung Kelir Jambu Kab Semarang. Perhitungan yang dilakukan metode ini berdasarkan dataset biji kopi arabika yang ada pada Perkebunan Kopi Lereng Gunung Kelir Jambu Semarang. Dimana dataset tersebut diambil dengan mewawancarai salah satu pihak yang mengelola Perkebunan Kopi Lereng Gunung Kelir Jambu Semarang dan juga sebagai ketua dari GAPOKTAN Perkebunan Kopi Lereng Gunung Kelir Jambu Semarang yakni bapak Ngadiyanto . Dataset itu sendiri terdiri dari data yang berasal dari karung karung biji kopi yang sudah terbagi berdasarkan kriteria nilai cacat,kadar air, dan ketinggian lahan selain data karung biji kopi arabika, juga parameter standar yang digunakan oleh Perkebunan Kopi Lereng Gunung kelir Jambu Semarang untuk mengukur kualitas biji kopi arabika berada pada grade 1, grade 2, atau grade 3. Proses pada perhitungan metode AHP pada penentuan kualitas biji kopi arabika yang ada pada Perkebunan Kopi Lereng Gunung Kelir Jambu Semarang dapat dilihat pada gambar berikut ini:

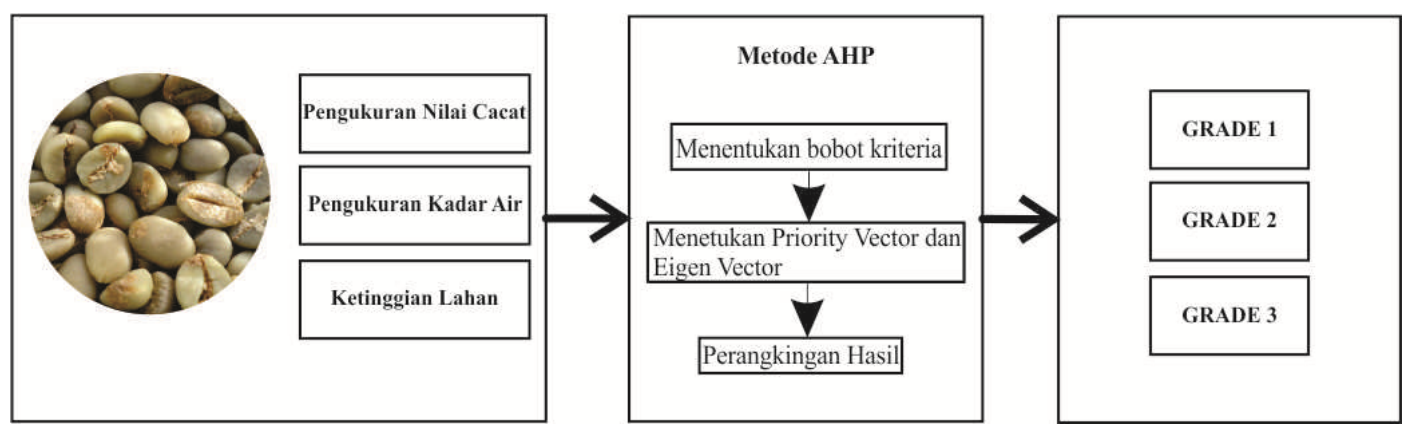

Gambar 1. Alur Perhitungan Metode AHP

Dapat dilihat pada gambar 1 bahwa secara garis besar penentuan kualitas biji kopi dengan metode AHP dimulai dari menentukan bobot kriteria, menentukan priority vector dan eigen vector lalu perangkingan hasil. Kriteria penentuan yang digunakan adalah kriteria nilai cacat, kadar air, dan ketinggian lahan, dimana dari ketiga kriteria tersebut maka akan dilakukan perbandingan berpasangan kriteria untuk menentukan bobot kriteria..

\section{HASIL DAN PEMBAHASAN}

Dalam perhitungan metode Analythical Hierarchy Process (AHP) terdapat tahap-tahap untuk mendapatkan hasil dari metode AHP yang berupa urutan nilai yang akan dijadikan sebagai perangkingan dalam menentukan kualitas biji kopi. Di dalam penentuan kualitas biji kopi arabika dengan menggunakan metode AHP maka tahap-tahap yang harus terlebih dahulu di lakukan adalah:

\subsection{Menentukan Struktur Hierarki}

Struktur hierarki yang ada pada Metode AHP ini ada beberapa tingkatan / level sesuai dengan kriteria apa saja yang ingin dimasukan ke dalam penentuan kualitas biji kopi tersebut, dimulai dari level 0 yaitu berisi Goal atau tujuan dari penentuan, tujuan didalam penentuan kualitas biji kopi adalah kualitas biji kopi, lalu level selanjutnya adalah level 1 yaitu level 1 disini berisi semua kriteria yang akan dijadikan sebagai acuan dalam penentuan terhadap goal. Level 1 dalam penentuan kualitas biji kopi adalah variabel kadar air, variabel cacat biji, dan variabel ketinggian lahan. Selanjutnya ialah level 2 dimana level 2 berisi tentang semua sub kriteria yang dapat mempengaruhi penentuan dari kriteria yang ada pada level 1 , level 2 ini berisi nilai sangat baik, baik, dan cukup dimana level 2 ini mengisi semua kriteria yang ada pada level 1. Sebagai contoh gambar struktur hierarki Penentuan Kualitas Biji Kopi Lereng Gunung Kelir Jambu Semarang adalah sebagai berikut: 


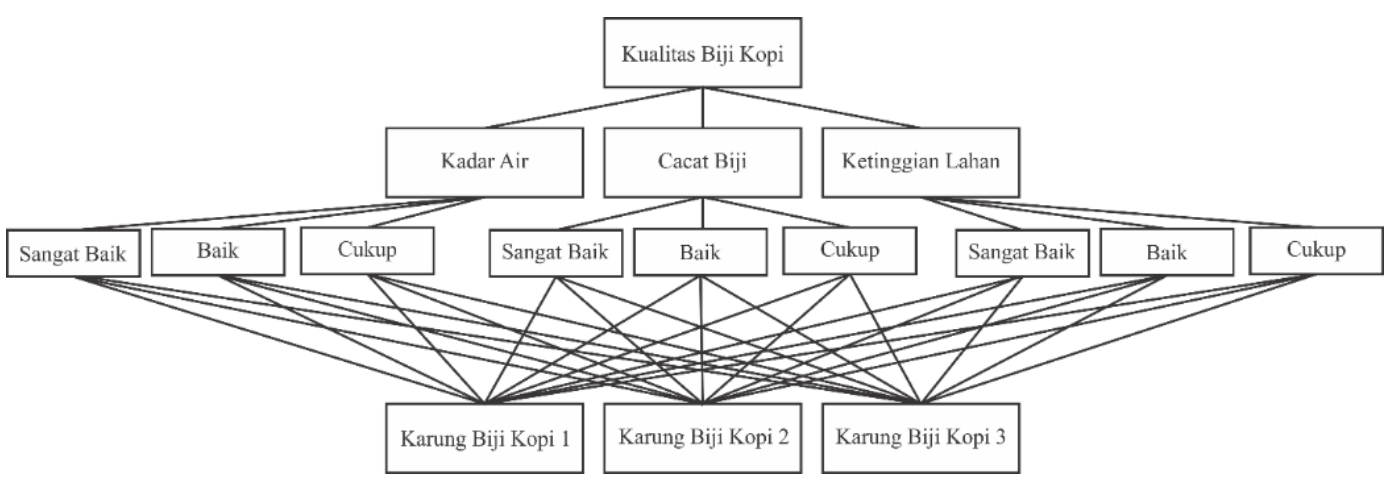

\section{Gambar 2. Struktur Hierarki Penentuan Kualitas Biji Kopi Arabika Perkebunan Kopi Lereng Gunung Kelir Jambu Semarang}

Pada gambar 2 dapat diketahui bahwa level 0 / Goal dalam menentukan kualitas biji kopi arabika Perkebunan Kopi Lereng Gunung Kelir Jambu Semarang adalah Kualitas Biji kopi. Pada level 1 terdapat kadar air, cacat biji, dan ketinggian lahan dimana ketiga kriteria tersebut yang dapat di jadikan acuan atau yang dapat mempengaruhi Goal. Level 2 terdapat sub kriteria sangat baik, baik, dan cukup dimana ketiga sub kriteria tersebut dijadikan acuan untuk setiap kriteria penentuan yang berada pada level 1 .

\subsection{Membuat Perbandingan Berpasangan Dan Menentukan Nilai Tingkat Kepentingan Dari Setiap Kriteria Dan Sub Kriteria}

Membuat perbandingan berpasangan pada kriteria dan sub kriteria penentuan dalam hal ini memberikan bobot atau nilai tingkat kepentingan dari tiap masing-masing pasangan kriteria dan sub kriteria dengan skala SAATY. Untuk dapat memberikan nilai tingkat kepentingan yang sesuai dengan penentuan kualitas biji kopi pada perkebunan kopi lereng gunung kelir maka dilakukan kajian lebih lanjut dari data maupun syarat penentuan kualitas biji kopi yang ada pada Perkebunan Kopi Lereng Gunung Kelir Jambu Semarang. Berikut adalah nilai tingkat kepentingan kriteria dan sub kriteria penentuan kualitas biji kopi arabika Perkebunan Kopi Lereng Gunung Kelir Jambu Semarang.

Tabel 1. Perbandingan berpasangan kriteria

\begin{tabular}{lccc}
\hline & Kadar Air & Cacat Biji & Ketinggian Lahan \\
\hline Kadar Air & 1 & 3 & 5 \\
Cacat Biji & $1 / 3$ & 1 & 4 \\
Ketinggian Lahan & $1 / 5$ & $1 / 4$ & 1 \\
\hline
\end{tabular}

Tabel 2. Perbandingan berpasangan kriteria sub kriteria kadar air

\begin{tabular}{lcccc}
\hline & Sangat Baik & Baik & Cukup \\
\hline Sangat Baik & 1 & 3 & 4 \\
Baik & $1 / 3$ & 1 & 2 \\
Cukup & $1 / 4$ & $1 / 2$ & 1 \\
\hline
\end{tabular}

Tabel 3. Perbandingan berpasangan kriteria sub kriteria cacat biji biji

\begin{tabular}{lcccc}
\hline & Sangat Baik & Baik & Cukup \\
\hline Sangat Baik & 1 & 3 & 4 \\
Baik & $1 / 3$ & 1 & 2 \\
Cukup & $1 / 4$ & $1 / 2$ & 1 \\
\hline
\end{tabular}


Tabel 4. Perbandingan berpasangan kriteria sub kriteria ketinggian lahanbiji

\begin{tabular}{lccc}
\hline & Sangat Baik & Baik & Cukup \\
\hline Sangat Baik & 1 & 3 & 4 \\
Baik & $1 / 3$ & 1 & 2 \\
Cukup & $1 / 4$ & $1 / 2$ & 1 \\
\hline
\end{tabular}

Pada tabel 1 tersebut jika kriteria 1 dibandingkan dengan kriteria yang sama maka akan langsung bernilai 1. Kriteria kadar air dibandingkan dengan cacat biji bernilai 3 karena 3 dalam skala Saaty berarti "Sedikit Lebih Penting" maka dalam penentuan kualitas biji kopi arabika bahwa kadar air "Sedikit Lebih Penting daripada cacat biji". kadar air dan ketinggian lahan bernilai 5 karena nilai 5 pada skala Saaty berarti "Jelas Lebih Penting" maka dalam penentuan kualitas biji kopi arabika bahwa kadar air sangat mempengaruhi apabila di bandingkan dengan ketinggian lahan. Kriteria cacat biji dibandingkan dengan kriteria ketinggian lahan bernilai 4 pada skala Saaty niali 4 berarti "Sedikit Lebih Hingga Jelas Lebih Penting".

Pada tabel 2, tabel 3, dan tabel 4 merupakan tabel perbandingan berpasangan sub kriteria dari masing-masing kriteria penentuan kualitas biji kopi arabika. Dimana sub kriteria sangat baik dibandingkan dengan sub kriteria baik maka akan bernilai 3 dimana nilai 3 dalam skala Saaty berarti "Sedikit Lebih Penting". Sub kriteria sangat baik dibandingkan dengan sub kriteria cukup maka akan bernilai 4 karena nilai 4 pada skala Saaty berarti "Sedikit Lebih Hingga Jelas Lebih Penting”. Sub kriteria baik dibandingkan denga sub kriteria cukup maka akan bernilai 2 yang mana pada skala Saaty nilai 2 berarti "Sama Hingga Sedikit Lebih Penting".

\subsection{Mencari Nilai Priority Vector Dan Eigen Vector}

Dalam mencari nilai priority vector dan eigen vector untuk kriteria dan sub kriteria maka dari tabel perbandingan berpasangan dilakukan normalisasi kolom unuk dapat mendapatkan nilai priority vector dan eigen vector. Dengan cara membagi setiap nilai yang ada pada kolom tabel 1 dengan jumlah setiap nilai pada kolom tabel 1 . Berikut adalah hasil normalisasi kolom pada tabel 1 yang ditunjukan oleh tabel 5 .

Tabel 5. Hasil normalisasi kolom kriteria

\begin{tabular}{lrrc}
\hline & Kadar $\boldsymbol{A i r}$ & Cacat Biji & Ketinggian Lahan \\
\hline Kadar Air & 0.652 & 0.706 & 0.500 \\
Cacat Biji & 0.217 & 0.235 & 0.400 \\
Ketinggian & 0.130 & 0.059 & 0.100 \\
Lahan & & & \\
\hline
\end{tabular}

Tabel 6. Nilai priority vector kriteria

\begin{tabular}{lrrcc}
\hline & Kadar Air & Cacat Biji & Ketinggian Lahan & Priority vector \\
\hline Kadar Air & 0.652 & 0.706 & 0.500 & 0.619 \\
Cacat Biji & 0.217 & 0.235 & 0.400 & 0.284 \\
Ketinggian Lahan & 0.130 & 0.059 & 0.100 & 0.096 \\
\hline
\end{tabular}

Setelah di dapatkan normalisasi kolom untuk masing-masing nilai yang ada pada tabel 1 maka dalam mencari priority vector langkah selanjutnya ialah menjumlah kan semua nilai yang ada baris tabel 5 dan hasil dari penjumahan baris tersebut akan dibagi dengan banyaknya kriteria penentuan yang digunakan dalam hal ini total krteria untuk menentukan kualitas biji kopi arabika pada Perebunan Kopi Lereng Gunung Kelir Jambu Semarang ialah 3. Maka jumlah dari nilai tiap baris tabel 5 akan di bagi dengan 3. Sebelum nilai priority vector tersebut dapat digunakan sebagai penentuan maka perlu di ketahui indeks konsistensinya (CR) apabila indeks konsistensi kurang dari sama dengan 0.1 maka konsisten apabila lebih dari 0.1 maka tidak konsisten dan harus diulang dalam menentukan priority vectornya. 
Mencari indeks konsistensi

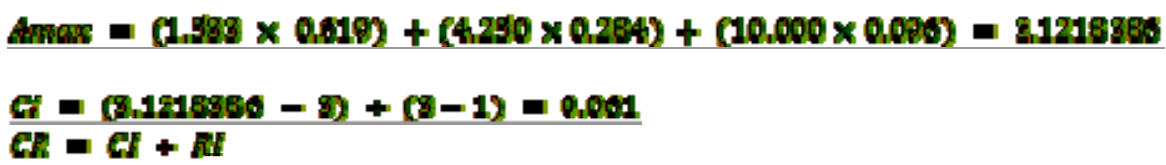

dimana RI merupakan nilai indeks random, nilai indeks random untuk kriteria yang berjumlah 3 yaitu 0.580

$G=G+N=0.01+0.560=0.1$

Karena $\mathrm{CR}=0.1$ maka konsisten untuk nilai Priority Vector untuk kriteria utama

Tabel 7. Eigen vector kriteria kadar air

\begin{tabular}{llcll}
\hline & Sangat Baik & Baik & Cukup & Eigen Vector \\
\hline Sangat Baik & 0.632 & 0.667 & 0.571 & 0.623 \\
Baik & 0.211 & 0.222 & 0.286 & 0.239 \\
Cukup & 0.158 & 0.111 & 0.143 & 0.137 \\
\hline
\end{tabular}

Tabel 8. Eigen vector kriteria cacat biji

\begin{tabular}{lllll}
\hline & Sangat Baik & Baik & Cukup & Eigen Vector \\
\hline Sangat Baik & 0.632 & 0.667 & 0.571 & 0.623 \\
Baik & 0.211 & 0.222 & 0.286 & 0.239 \\
Cukup & 0.158 & 0.111 & 0.143 & 0.137 \\
\hline
\end{tabular}

Tabel 9 Eigen vector kriteria ketinggian lahan

\begin{tabular}{llcll}
\hline & Sangat Baik & Baik & Cukup & Eigen Vector \\
\hline Sangat Baik & 0.632 & 0.667 & 0.571 & 0.623 \\
Baik & 0.211 & 0.222 & 0.286 & 0.239 \\
Cukup & 0.158 & 0.111 & 0.143 & 0.137 \\
\hline
\end{tabular}

Pada tabel 7, tabel 8, dan tabel 9 langkah-langkah dalam penentuan eigen vector sama dengan langkah-langkah yang dilakukan dalam menentukan priority vector. Dimana langkah pertama ialah menormalisasi kolom pada setiap nilai kolom yang ada pada tabel lalu selanjutnya dilakukan pembagian antara jumlah baris dari hasil normalisasi kolom dengan total kriteria yang digunakan dalam penentuan daam hal ini total 3 sangat baik, baik, dan cukup.

\subsection{Perangkingan Alternatif Untuk Menentukan Kualitas Biji Kopi Arabika}

Untuk dapat melakukan perangkingan, pada hal ini data sampel kopi arabika harus disingkronkan dengan sub kualitas berdasarkan sub kualitas dari Kadar Air, Cacat Biji, maupun Ketinggian Lahan sesuai dengan standar penentuan kualitas biji kopi yang ada pada Perkebunan Lereng Kopi Gunung Kelir Jambu Semarang. Standar kualitas penentuan kualitas biji kopi pada Perkebunan Kopi Lereng Gunung Kelir Jambu Semarang seperti berikut ini: 
Tabel 10. Standar nilai penentuan kualitas biji kopi arabika

\begin{tabular}{ccc}
\hline Kriteria & Point & Standar Nilai \\
\hline Kadar Air & I & $<15$ \\
& II & $15-18$ \\
Cacat Biji & III & $>18$ \\
& I & $<1 \%$ \\
Ketinggian Lahan & II & $>2 \%$ \\
& III & $<800 \mathrm{mdpl}$ \\
& I & $800-1900 \mathrm{mdpl}$ \\
& II & $>1900 \mathrm{mdpl}$ \\
\hline
\end{tabular}

Untuk dapat tabel sampel data kopi dihitung dengan sub kriteria, maka tabel data kopi diubah menurut poin penentuan kualitas biji kopi yang ada pada Perkebunan Lereng Gunung Kelir Jambu Semarang, dalam hal ini pada tabel 8 peneliti mengibaratkan bahwa poin I adalah Sangat Baik, poin II adalah Baik, dan poin III adalah Cukup. Untuk lebih jelasnya dapat dilihat pada tabel 9 dan tabel 10 berikut ini:

Tabel 11. Sampel data kopi

\begin{tabular}{ccccc}
\hline No & Data Sampel & Kadar Air & Cacat Biji & Ketinggian Lahan \\
\hline 1 & Karung Kopi 1 & 10 & 0.1 & 900 \\
2 & Karung Kopi 2 & 11 & 1.5 & 900 \\
3 & Karung Kopi 3 & 13 & 2.0 & 900 \\
4 & Karung Kopi 4 & 10 & 0.9 & 900 \\
5 & Karung Kopi 5 & 0.7 & 15 & 900 \\
\hline
\end{tabular}

Singkronisasi tabel 11 menjadi tabel 12 mengacu pada standar nilai penentuan kualitas biji kopi arabika Perkbunan Kopi Lereng Gunung Kelir Jambu Semarang yang teradapat pada tabel 10. Sebagai contoh pada Karung Kopi 1 dimana mempunyai kadar air bernilai 10, cacat biji bernilai 0.1 , dan ketinggian lahan bernilai 900. Kadar air bernilai 10 merujuk pada poin 1 pada tabel 10 dimana poin 1 adalah dimana nilai kadar airnya kurang dari 15 . Cacat biji bernilai 0.1 yang mana merujuk pada poin 1 yang ada pada tabel 10 bagian kriteria cacat biji dimana 0.1 memenuhi syarat poin 1 yang mana apabila nilai cacat biji nya kurang dari 1\% maka termasuk kedalam poin 1 . Ketinggian lahan karung biji kopi 1 bernilai 900 dimana 900 memenuhi poin 2 pada standar kriteria ketinggian lahan yang ada pada tabel 10 .

Tabel 12 Sinkronisasi sampel data kopi

\begin{tabular}{cllll}
\hline No & Data Sampel & Kadar Air & \multicolumn{1}{c}{ Cacat Biji } & Ketinggian Lahan \\
\hline 1 & Karung Kopi 1 & Sangat Baik & Sangat Baik & Baik \\
2 & Karung Kopi 2 & Sangat Baik & Baik & Baik \\
3 & Karung Kopi 3 & Baik & Baik & Baik \\
4 & Karung Kopi 4 & Sangat Baik & Cukup & Cukup \\
5 & Karung Kopi 5 & Baik & Sangat Baik & Cukup \\
\hline
\end{tabular}

Untuk dapat menghasilkan sebuah rangking atau perangkingan alternatif maka akan dilakukan perhitungan seperti berikut: Rangking Karung Kopi Biji I = (Priority vector kadar air x Eigen vector kadar air) + (Priority vector cacat biji $\mathrm{x}$ Eigen vector cacat biji) $\mathrm{x}$ (Priority vector tinggi lahan $\mathrm{x}$ Eigen vector tinggi lahan) Dalam hal ini pada tabel 10 jika data sampel kopi menyebutkan Sangat Baik pada kriteria Kadar Air maka Eigen Vector dari Sub kriteria Sangat Baik pada kriteria Kadar Air, akan dipakai sebagai perhitungan, jika menyebutkan Baik maka Eigen Vector nya juga yang akan diambil yaitu nilai Eigen Vector Baik pada kriteria Kadar Air, begitu juga pada sub kriteria Cukup. 
Contoh perhitungannya seperti berikut :

Karung Biji Kopi $1=(0.619 \times 0.623)+(0.284 \times 0.623)+(0.096 \times 0.239)=0.586$

Karung Biji Kopi $2=(0.619 \times 0.623)+(0.284 \times 0.239)+(0.096 \times 0.239)=0.476$

Karung Biji Kopi $3=(0.619 \times 0.239)+(0.284 \times 0.239)+(0.096 \times 0.239)=0.239$

Karung Biji Kopi $4=(0.619 \times 0.623)+(0.284 \times 0.137)+(0.096 \times 0.137)=0.438$

Karung Biji Kopi $5=(0.619 \times 0.239)+(0.284 \times 0.623)+(0.096 \times 0.137)=0.338$

Tabel 13. Tabel hasil perhitungan rangking alternatif

\begin{tabular}{cc}
\hline Data sampel & Rangking alternatif \\
\hline Karung Kopi 1 & 0.586 \\
Karung Kopi 2 & 0.476 \\
Karung Kopi 3 & 0.239 \\
Karung Kopi 4 & 0.438 \\
Karung Kopi 5 & 0.338 \\
\hline
\end{tabular}

Tabel 11 merupakan tabel hasil dari perhitungan perangkingan alternatif dari data sampel yang ada pada tabel 10. Dimana Karung Kopi 1 mempunyai nilai tertinggi dan karung Biji Kopi 3 mempunyai nilai paling rendah dari kelima data sampel. Untuk dapat di dapatkan grade 1, grade 2, atau grade 3 maka apabila nilai rangking alternatif tersebut kurang dari 0.2 maka data kopi arabika tersebut berada pada grade 3, untuk grade 2 apabila data kopi arabika tersebut bernilai antara 0.2 dan 0.4 , sedangkan untuk grade 1 apabila nilai rangking alternatifnya berada di atas 0.4 .

Tabel 14. Kualitas biji kopi arabika dari data sampel

\begin{tabular}{cc}
\hline Data Sampel & Rangking Alternatif \\
\hline Karung Kopi 1 & Grade 1 \\
Karung Kopi 2 & Grade 1 \\
Karung Kopi 3 & Grade 3 \\
Karung Kopi 4 & Grade 2 \\
Karung Kopi 5 & Grade 2 \\
\hline
\end{tabular}

3.5 Akurasi Perhitungan Metode Ahp Dengan Perhitungan Manual Penentuan Kualitas Biji Kopi Arabika Pada Perkebunan Kopi Lereng Gunung Kelir Jambu Semarang

Tabel 15. Akurasi Data Karung Biji Kopi

\begin{tabular}{|c|c|c|c|c|c|c|}
\hline No & $\begin{array}{l}\text { Karung } \\
\text { Biji Kopi }\end{array}$ & $\begin{array}{c}\text { Nilai } \\
\text { Kadar } \\
\text { Air }\end{array}$ & $\begin{array}{c}\text { Nilai } \\
\text { Cacat } \\
\text { Biji }\end{array}$ & $\begin{array}{c}\text { Ketinggian } \\
\text { Lahan }\end{array}$ & $\begin{array}{c}\text { Data Kualitas } \\
\text { Perhitungan } \\
\text { Manual }\end{array}$ & $\begin{array}{c}\text { Data Kualitas } \\
\text { Perhitungan } \\
\text { AHP }\end{array}$ \\
\hline 1 & $\begin{array}{l}\text { Karung Biji } \\
\text { Kopi } 1\end{array}$ & 8 & 0.1 & 1100 & Grade 1 & Grade 1 \\
\hline 2 & $\begin{array}{l}\text { Karung Biji } \\
\text { Kopi } 2\end{array}$ & 8 & 0.3 & 1100 & Grade 1 & Grade 1 \\
\hline 3 & $\begin{array}{l}\text { Karung Biji } \\
\text { Kopi } 3\end{array}$ & 10 & 1.0 & 1100 & Grade 1 & Grade 1 \\
\hline 4 & $\begin{array}{l}\text { Karung Biji } \\
\text { Kopi } 4\end{array}$ & 8 & 1.0 & 1100 & Grade 1 & Grade 1 \\
\hline 5 & $\begin{array}{l}\text { Karung biji } \\
\text { Kopi } 5\end{array}$ & 10 & 2.5 & 1100 & Grade 2 & Grade 1 \\
\hline 6 & $\begin{array}{l}\text { Karung Biji } \\
\text { Kopi } 6\end{array}$ & 15 & 1.5 & 1100 & Grade 2 & Grade 2 \\
\hline 7 & $\begin{array}{l}\text { Karung Biji } \\
\text { Kopi } 7\end{array}$ & 15 & 1 & 1100 & Grade 2 & Grade 2 \\
\hline 8 & $\begin{array}{l}\text { Karung Biji } \\
\text { Kopi } 8\end{array}$ & 9 & 2 & 1100 & Grade 2 & Grade 1 \\
\hline 9 & $\begin{array}{l}\text { Karung Biji } \\
\text { Kopi } 9\end{array}$ & 20 & 1 & 1100 & Grade 3 & Grade 3 \\
\hline 10 & $\begin{array}{l}\text { Karung Biji } \\
\text { Kopi } 10\end{array}$ & 20 & 1.5 & 1100 & Grade 3 & Grade 3 \\
\hline
\end{tabular}




\begin{tabular}{|c|c|c|c|c|c|c|}
\hline No & $\begin{array}{l}\text { Karung } \\
\text { Biji Kopi }\end{array}$ & $\begin{array}{c}\text { Nilai } \\
\text { Kadar } \\
\text { Air }\end{array}$ & $\begin{array}{c}\text { Nilai } \\
\text { Cacat } \\
\text { Biji }\end{array}$ & $\begin{array}{c}\text { Ketinggian } \\
\text { Lahan }\end{array}$ & $\begin{array}{c}\text { Data Kualitas } \\
\text { Perhitungan } \\
\text { Manual }\end{array}$ & $\begin{array}{c}\text { Data Kualitas } \\
\text { Perhitungan } \\
\text { AHP }\end{array}$ \\
\hline 11 & $\begin{array}{l}\text { Karung Biji } \\
\text { Kopi } 11\end{array}$ & 7 & 0.3 & 1500 & Grade 1 & Grade 1 \\
\hline 12 & $\begin{array}{l}\text { Karung Biji } \\
\text { Kopi } 12\end{array}$ & 8 & 0.3 & 1500 & Grade 1 & Grade 1 \\
\hline 13 & $\begin{array}{l}\text { Karung Biji } \\
\text { Kopi } 13\end{array}$ & 10 & 2.0 & 1500 & Grade 1 & Grade 1 \\
\hline 14 & $\begin{array}{l}\text { Karung Biji } \\
\text { Kopi } 14\end{array}$ & 7 & 2.5 & 1500 & Grade 2 & Grade 1 \\
\hline 15 & $\begin{array}{l}\text { Karung Biji } \\
\text { Kopi } 15\end{array}$ & 15 & 2.0 & 1500 & Grade 2 & Grade 2 \\
\hline 16 & $\begin{array}{l}\text { Karung Biji } \\
\text { Kopi } 16\end{array}$ & 15 & 1.0 & 1500 & Grade 2 & Grade 2 \\
\hline 17 & $\begin{array}{l}\text { Karung Biji } \\
\text { Kopi } 17\end{array}$ & 15 & 2.0 & 1500 & Grade 2 & Grade 2 \\
\hline 18 & $\begin{array}{l}\text { Karung Biji } \\
\text { Kopi } 18\end{array}$ & 9 & 1.0 & 1500 & Grade 1 & Grade 1 \\
\hline 19 & $\begin{array}{l}\text { Karung Biji } \\
\text { Kopi } 19\end{array}$ & 20 & 1.5 & 1500 & Grade 3 & Grade 3 \\
\hline 20 & $\begin{array}{l}\text { Karung Biji } \\
\text { Kopi } 20\end{array}$ & 20 & 2.0 & 1500 & Grade 3 & Grade 3 \\
\hline & $\begin{array}{l}\text { il Presentasi } \\
\text { Error }\end{array}$ & & & & \multicolumn{2}{|c|}{$15 \%$} \\
\hline & $\begin{array}{l}\text { il Presentasi } \\
\text { eakuratan }\end{array}$ & & & & \multicolumn{2}{|c|}{$85 \%$} \\
\hline
\end{tabular}

Dari data kopi yang terdapat pada tabel 15 terdapat presentasi error sebesar $15 \%$ dimana $15 \%$ tersebut merupakan ketidak akuratan antara data perhitungan manual dengan perhtitungan dengan metode AHP yang ditunjukan oleh karung biji kopi 5, karung biji kopi 8 dan karung biji kopi 14 dari total 20 data yang di bandingkan.

\section{KESIMPULAN}

Metode AHP dapat digunakan sebagai metode penentuan kualitas biji kopi arabika pada Perkebunan Kopi Lereng Gunung Kelir Jambu Semarang dengan akurasi sebesar 85\% dari total 20 data yang diuji.

\section{UCAPAN TERIMA KASIH}

Peneliti mengucapkan terima kasih kepada kedua orang tua dan pihak Universitas Dian Nuswantoro Semarang yang telah memberi dukungan dan semangat untuk menyelesaikan penelitian ini. Terima kasih juga kepada disampaikan kepada pihak-pihak yang telah membantu peneliti selama penyelesaian penelitian ini..

\section{DAFTAR PUSTAKA}

[1] Ningtyas O, I., dan Trilaksana, A. 2014. "Perkebunan Kopi Rakyat di Jawa Timur 1920-1942.," AVATARA, e-Journal Pendidikan Sejarah, vol. 2, pp. 122-129.

[2] J. J. Kusumo. 2014 "Rancang Bangun Perangkat Lunak Mengklasifikasi Kualitas Biji Kopi Dengan Metode Backpropagation (Studi Kasus : Material Warehouse PT. Santos Jaya Abadi)," Jurnal Tugas Akhir Universitas Narotama, pp. 1-10.

[3] Darmanto, E., Latifah, N., dan Nanik, S. 2014. "Penerapan Metode AHP (Analytical Hierarchy Process) Untuk Menentukan Kualitas Gula Tumbu." Jurnal SIMETRIS, vol. 5.

[4] Tatang, S, U., dan Eka, P, R. 2015. "Implementasi Algoritma C4.5 Dalam Penentuan Kualitas Tomat," Jurnal Teknologi Informasi dan Komunikasi, pp. 1-16. 
Jurnal SIMETRIS, Vol 8 No 2 November 2017

ISSN: 2252-4983

[5] Mazenda, G., Andy, S, A., dan Dewi, C. 2014. Fuzzy Inference System (FIS) Metode Tsukamoto Pada Sistem Pendukung Keputusan Penentuan Kualitas Air Sungai," Journal Of Environmental Engineering \& Sustainable Technology, vol. 01 NO. 02, pp. 1-12. 